\title{
Pertumbuhan Kalus dan Produksi Katekin pada Kultur In Vitro Kalus Teh (Camelia Sinensis L.) dengan Penambahan Elisitor $\mathrm{Ca}^{2+}$ dan $\mathrm{Cu}^{2+}$
}

\section{Callus Growth and Catechin Production on In Vitro Culture of Tea Callus (Camelia Sinensis $\mathrm{L}$.) with the Addition of $\mathrm{Ca}^{2+}$ and $\mathrm{Cu}^{2+}$ Elicitors}

\author{
Dewi Retnaningati ${ }^{1 *}$, Hermanto ${ }^{1}$, Ekawati Purwijantiningsih ${ }^{1}$, Hartini Realista Lydia Solle ${ }^{2}$ \\ ${ }^{1}$ Prodi Biologi, Fakultas Teknobiologi, Universitas Atma Jaya Yogyakarta \\ Jl. Babarsari No. 44, Sleman, Daerah Istimewa Yogyakarta, Indonesia \\ ${ }^{2}$ Prodi Pendidikan Biologi, Fakultas Keguruan dan Ilmu Pendidikan, Universitas Kristen Artha Wacana \\ Jl. Adisucipto 147 Oesapa, Kupang, Nusa Tenggara Timur, Indonesia \\ Email: dewi.retnaningati@uajy.ac.id \\ *Penulis Korespondensi
}

\begin{abstract}
Antioxidants can reduce the negative impact of oxidants in the body. Tea is one source of natural antioxidants that contain polyphenolic antioxidants, namely catechins which have four derivatives, namely: epicatechin (EC), epicatechin error (ECG), epigalocatechin (EGC), and epigalocatechin error (EGCG). The level of catechins in tea will decrease due to the process of making tea from fresh tea leaves into steeping tea, so there needs to be an effort to increase the content of catechins in tea. This study aims to examine the method of increasing the production of catechins in tea callus culture. The treatment was carried out by giving elicitor $\mathrm{Ca} 2+$ and $\mathrm{Cu} 2+$ on tea callus culture medium with various concentrations designed in 9 treatments, namely: $\mathbf{U}_{0} A_{0}, U_{0} A_{1}, U_{0} A_{2}, U_{1} A_{0}, U_{1} A_{1}, U_{1} A_{2}, U_{2} A_{0}, U_{2} A_{1}, U_{2} A_{2}$, where $U^{0}=$ $\mathrm{Cu}^{2}+$ treatment. $0 \mathrm{~g} / \mathrm{L}, \mathrm{U}^{1}=\mathrm{Cu}^{2+}$ treatment $1 \mathrm{~g} / \mathrm{L}, \mathrm{U}^{2}=\mathrm{Cu}^{2+}$ treatment $2 \mathrm{~g} / \mathrm{L}, \mathrm{A}^{0}=\mathrm{Ca}^{2+}$ treatment $0 \mathrm{~g} / \mathrm{L}, \mathrm{A}^{1}=\mathrm{Ca}^{2+}$ treatment $176 \mathrm{~g} / \mathrm{L}$, and $\mathrm{A}^{2}=\mathrm{Ca}^{2+}$ treatment $352 \mathrm{~g} / \mathrm{L}$. All treatments were incubated for 10 days with harvest time on day 0,5 , and 10 . The results showed that the most optimal combination of elicitor $\mathrm{Ca}^{2+}$ and $\mathrm{Cu}^{2+}$ in increasing levels of error epicatechin in tea callus culture (C. sinensis L.) was $U^{1} A^{1}$ treatment with a combination of concentrations of $\mathrm{Ca}^{2+}(176 \mathrm{~g} / \mathrm{L})$ and $\mathrm{Cu}^{2+}(1 \mathrm{~g} / \mathrm{L})$ during 0 days (less than 24 hours) with the highest error epicatechin production of $298.37 \mathrm{ppm}$.
\end{abstract}

Keywords: callus culture, catechins, error epicatechin, Camelia sinensis, elicitor, $\mathrm{Ca}^{2+}, \mathrm{Cu}^{2+}$

\begin{abstract}
Abstrak
Antioksidan dapat mengurangi dampak negatif oksidan dalam tubuh. Teh merupakan salah satu sumber antioksidan alami yang memiliki antioksidan golongan polifenol yakni katekin yang memiliki empat turunan yaitu: epikatekin (EC), epikatekin galat (ECG), epigalokatekin (EGC), dan epigalokatekin galat (EGCG). Kadar katekin pada teh akan turun karena proses pembuatan teh dari daun teh segar menjadi teh seduhan, sehingga perlu ada upaya peningkatan kandungan katekin dalam teh. Penelitian ini bertujuan untuk mengkaji metode peningkatan produksi katekin pada kultur kalus teh. Perlakukan yang dilakukan yaitu dengan penambahan elisitor $\mathrm{Ca}^{2+}$ dan $\mathrm{Cu}^{2+}$ pada medium kultur kalus teh dengan berbagai variasi konsentrasi yang dirancang dalam 9 perlakuan yaitu: $U_{0} A_{0}, U_{0} A_{1}$, $\mathrm{U}_{0} A_{2}, \mathrm{U}_{1} A_{0}, \mathrm{U}_{1} A_{1}, \mathrm{U}_{1} A_{2}, \mathrm{U}_{2} A_{0}, \mathrm{U}_{2} \mathrm{~A}_{1}, \mathrm{U}_{2} \mathrm{~A}_{2}$, di mana $\mathrm{U}_{0}=$ perlakuan $\mathrm{Cu}^{2+} \mathbf{g} / \mathrm{L}, \mathrm{U}_{1}=$ perlakuan $\mathrm{Cu}^{2+} 1 \mathrm{~g} / \mathrm{L}, \mathrm{U}_{2}=$ perlakuan $\mathrm{Cu}^{2+} 2 \mathrm{~g} / \mathrm{L}, \mathrm{A}_{0}=$ perlakuan $\mathrm{Ca}^{2+} \mathrm{O} \mathrm{g} / \mathrm{L}, \mathrm{A}_{1}=$ perlakuan $\mathrm{Ca}^{2+} 176 \mathrm{~g} / \mathrm{L}$, dan $\mathrm{A}_{2}=$ perlakuan $\mathrm{Ca}^{2+} 352 \mathrm{~g} / \mathrm{L}$. Semua perlakuan diinkubasi selama 10 hari dengan waktu panen yaitu pada hari ke-0, ke-5, dan ke-10. Hasil Penelitian menunjukkan kombinasi elisitor $\mathrm{Ca}^{2+}$ dan $\mathrm{Cu}^{2+}$ yang paling optimal dalam meningkatkan kadar epikatekin galat pada kultur kalus teh $\left(C\right.$. sinensis $L_{\text {.) }}$ yaitu perlakuan $\mathrm{U}_{1} \mathrm{~A}_{1}$ yaitu dengan kombinasi konsentrasi $\mathrm{Ca}^{2+}(176 \mathrm{~g} / \mathrm{L})$ dan $\mathrm{Cu}^{2+}(1 \mathrm{~g} / \mathrm{L})$ selama 0 hari (kurang dari 24 jam) dengan hasil produksi epikatekin galat tertinggi yaitu sebesar $298,37 \mathrm{ppm}$.
\end{abstract}

Keywords: kultur kalus, katekin, epikatekin galat, Camelia sinensis, elisitor, $\mathrm{Ca}^{2+} \mathbf{C u}^{2+}$ 


\section{Pendahuluan}

Pada era globalisasi, manusia semakin rentan terpapar oleh radikal bebas. Sumber radikal bebas dapat berasal dari asap kendaraan bermotor, asap pabrik, radiasi, makanan, dan juga proses oksidasi dalam tubuh. Radikal bebas dapat memicu timbulnya berbagai penyakit degeneratif. Beberapa penyakit degeneratif yang dipicu oleh radikal bebas antara lain kanker, jantung, serta diabetes. Melihat semakin rentannya manusia terserang penyakit degeneratif, dibutuhkan senyawa antioksidan yang dapat menangkap radikal bebas tersebut, sehingga tidak terjadi induksi penyakit (Kikuzaki dkk., 2012).

Antioksidan merupakan senyawa yang mampu menangkal atau meredam dampak negatif dari oksidan dalam tubuh dengan berfungsi sebagai donor proton. Antioksidan bekerja dengan cara mendonorkan satu protonnya kepada senyawa radikal bebas yang bersifat oksidan sehingga senyawa oksidan tersebut dapat dihambat (Winarsi, 2007). Keseimbangan oksidan dan antioksidan sangat penting karena berkaitan dengan imunitas tubuh terutama untuk menjaga integritas dan berfungsinya membran lipid, protein sel, asam nukleat, serta mengontrol transduksi sinyal dan ekspresi gen dalam sel imun.

Antioksidan menurut Prabantini (2010), dapat ditemukan dari sumber-sumber antioksidan yakni antioksidan sintetik dan antioksidan alami. Antioksidan sintetik merupakan antioksidan yang diperoleh dari hasil sintesis melalui reaksi kimia, antioksidan alami merupakan antioksidan hasil ekstraksi dari bahan alami. Resiko penggunaan produk sintetik telah mendorong kesadaran manusia modern untuk beralih ke produk alami, salah satu diantaranya dalam hal antioksidan alami.

Salah satu sumber antioksidan alami yang biasa dikonsumsi selain dari buah adalah teh. Teh menurut Rohdiana (2001), memiliki antioksidan golongan polifenol yakni katekin yang memiliki empat turunan yakni epikatekin (EC), epikatekin galat (ECG), epigalokatekin (EGC), dan epigalokatekin galat (EGCG). Menurut Rohdiana (2001), epigalokatekin galat (EGCG) dan epikatekin galat (ECG) merupakan senyawa utama katekin dalam teh. Epikatekin galat (ECG) merupakan salah satu turunan katekin yang memiliki daya antioksidan terbesar kedua selain epigalokatekin galat (EGCG). Oleh karena itu, epikatekin galat ini merupakan salah satu sumber antioksidan yang potensial.

Kadar katekin pada teh (Camelia sinensis L.) menurut Balittri (2013) adalah $13,5-31 \%$ dari berat kering daun teh segar dengan komposisi epigalokatekin galat adalah sekitar 5-14\% serta epikatekin galat sekitar 2 - $4 \%$. Senyawa epigalokatekin galat dan epikatekin galat ini merupakan derivat dari katekin yang merupakan salah satu substansi fenol golongan flavanol (Alamsyah, 2006). Selain senyawa fenol, Alamsyah (2006) juga menyebutkan bahwa teh memiliki kandungan lain seperti substansi penyebab aroma yakni klorofil, karotenoid, dan senyawa volatil, substansi bukan fenol seperti karbohidrat, substansi pektin, alkaloid, protein, vitamin, serta mineral.

Dengan berkembangnya teknologi dan ilmu pengetahuan, kandungan zat aktif pada suatu sediaan dapat dimaksimalkan. Salah satu upaya yang dapat digunakan adalah dengan elisitasi pada kultur (Hutami, 2009). Daun teh (Camellia sinensis L.) yang dikultur pada medium secara in vitro akan tumbuh kalus yang merupakan bahan utama elisitasi dalam kultur kalus.

Kalus merupakan kumpulan sel amorphous, tidak terorganisasi, dan belum berdiferensiasi yang terbentuk akibat luka sebagai respon perlindungan untuk menutup jaringan luka (Heryanto, 2014). Kalus akan tumbuh pada area irisan atau luka pada eksplan (Hendaryono dan Wijayanni, 1994). Menurut Hartman dkk. (1990), kalus dapat diinisiasi dari bagian serta organ-organ tanaman, namun masing-masing organ akan memberikan kecepatan pembelahan sel yang berbeda sehingga akan memengaruhi kecepatan pertumbuhan kalus yang berbeda juga.

Pertumbuhan kalus dapat dimanipulasi untuk meningkatkan produksi metabolit sekunder. Salah satu metodenya adalah dengan penambahan elisitor. Elisitor merupakan agen aktif yang akan memicu terbentuknya metabolit sekunder dengan menginduksi respon perlindungan diri tanaman (Caldentey dan Bars, 2002). Salah satu elisitor yang dapat digunakan adalah $\mathrm{Cu}^{2+}$ yang mampu meningkatkan kadar artemisinin pada kalus $A$. vulgaris secara in vitro (Jannah, 2016) dan berdasar hasil penelitian Ariningsih (2003), 
perlu dilakukan penelitian lanjutan dengan menurunkan konsentrasi penambahan ion $\mathrm{Cu} 2+$ dibawah 2,5 $\mathrm{mgl}-1$ pada media dasar Murashige-Skoog (MS) dan penambahan ion $\mathrm{Ca}^{2+}$ dibawah $440 \mathrm{mg} / \mathrm{l}$. Tingkat keasaman media kultur berpengaruh terhadap proses metabolisme sekunder dari tanaman. Pengasaman media dapat dilakukan dengan berbagai cara, seperti alkalisasi eksternal, penambahan yeast, pemberian asam lemah, maupun pemberian ion $\mathrm{Ca}^{2+}$ dalam media (Roos et al., 1998; Johannes et al., 1998).Oleh karena itu, penelitian ini menggunakan elisitor $\mathrm{Cu}^{2+}$ dan $\mathrm{Ca}^{2+}$ untuk meningkatkan produksi epikatekin galat pada kultur kalus daun teh (Camellia sinensis L.). Penggunaan elisitor bertujuan sebagai induktor dalam meningkatkan produksi metabolit sekunder dengan cara menstimulasi pembentukan senyawa fenol (epikatekin galat) (Junaira dkk., 2014;Purwianingsih dan Hamdiyati, 2007).

\section{Metode Penelitian}

\section{Alat dan Bahan}

Alat-alat yang akan digunakan dalam penelitian ini adalah neraca analitik, Erlenmeyer 1 L, Erlenmeyer $500 \mathrm{~mL}$, Erlenmeyer $100 \mathrm{~mL}$, milipore filter, botol kultur, kompor gas Rinnai, Kulkas, Freezer (Cool Lab), Laminair Flow (ESCO), autoklaf, pipet tetes, pipet ukur, pro pipet, skalpel, blade (MEG 10), cawan petri, gelas ukur, $\mathrm{pH}$ meter Ohaus, mortar, lumpang porselin, eksikator, centrifuge tube, sonikator, spektrofotometer Genesis 10S UV-Vis, centrifuge Hettich EBA3s, oven Venticell, mikropipet eppendorf, tip, centrifuge tube, platsilika $\mathrm{GF}_{254} \mathrm{CAMAG}$, penggaris, pensil, lampu UV CAMAG, tabung reaksi, rak tabung reaksi, ose, lampu spiritus, korek api, CAMAG TLC scanner 3, dan kuvet.

Bahan yang digunakan dalam penelitian ini adalah daun teh (daun ke-2 dan ke-3) yang diambil dari Nglinggo Kulon Progo dengan ciri-ciri berwarna hijau dan sehat, medium Murashige \& Skoog instan Caisson Lab, aquades steril, aquabides, Hormon Benzyl Aminopurine (BAP), Napthalene Acitic Acid (NAA), bacteriological agar OXOID, aluminium foil, cling wrap, etanol $70 \%$, sodium hipoklorit, Tween 20, kertas saring, $\mathrm{CaSO}_{4}, \mathrm{CuSo}_{4}$, sukrosa, metanol absolut, toluen, aseton, asam format, fungisida (Diathane M-45), bakteriosida (Agrept 20 WP), standar epikatekin galat, kertas payung, dan kapas.

\section{Rancangan Percobaan}

Penelitian yang dilakukan terdiri dari tiga tahapan utama yakni kultur kalus teh, elisitasi dan ekstraksi kalus hasil elisitasi, serta pengujian konsentrasi epikatekin galat dalam ekstrak kultur kalus hasil elisitasi. Rancangan perlakuan yang dilakukan disajikan dalam Tabel 1.

Rancangan percobaan penelitian pada penelitian ini menggunakan metode rancangan acak lengkap faktorial. Rancangan yang digunakan adalah $3 \times 3 \times 3$ dengan faktor berupa Elisitor $\mathrm{Ca}^{2+}$ dan Elisitor $\mathrm{Cu}^{2+}$ serta waktu pemanenan. Perlakuan konsentrasi $\mathrm{Ca}^{+}$yang digunakan adalah $176 \mathrm{~g} / \mathrm{L}$ dan $352 \mathrm{~g} / \mathrm{L}$ sedangkan $\mathrm{Cu}^{+}$adalah $1 \mathrm{~g} / \mathrm{L}$ dan $2 \mathrm{~g} / \mathrm{L}$, kombinasi kedua elisitor tersebut.

Tabel 1. Rancangan percobaan penambahan Elisitor $\mathrm{Ca}^{2+}$ dan Elisitor $\mathrm{Cu}^{2+}$ pada medium kultur kalus daun teh (C. sinensis L.)

\begin{tabular}{cccc}
\hline \hline \multirow{2}{*}{ Konsentrasi Ca ${ }^{2+}$} & & Konsentrasi $\mathbf{C u}^{2+}$ & U2 \\
\cline { 2 - 4 } & U0 & U1 & U2A0 \\
A0 & U0A0 & U1A0 & U2A1 \\
A1 & U0A1 & U1A2 & U2A2 \\
\hline \hline
\end{tabular}

Keterangan : $\mathbf{U}_{0}$ perlakuan $\mathrm{Cu}^{2+} 0 \mathrm{~g} / \mathrm{L}, \mathbf{U}_{1}$ perlakuan $\mathrm{Cu}^{2+} 1 \mathrm{~g} / \mathrm{L}, \mathbf{U}_{2}$ perlakuan $\mathrm{Cu}^{2+} 2 \mathrm{~g} / \mathrm{L}$, Ao perlakuan $\mathrm{Ca}^{2+} 0 \mathrm{~g} / \mathrm{L}, \mathbf{A}_{1}$ perlakuan $\mathrm{Ca}^{2+} 176 \mathrm{~g} / \mathrm{L}, \mathbf{A}_{2}$ perlakuan $\mathrm{Ca}^{2+} 352 \mathrm{~g} / \mathrm{L}$. 


\section{Prosedur Kerja}

Tahapan yang dilakuakn dalam penelitian ini adalah sebagai berikut.

1. Pembuatan Larutan Stok Hormon Benzyl Aminopurine (BAP) dan Napthalene Acitic Acid (NAA)

Pembuatan larutan stok dilakukan dengan cara masing-masing hormon BAP dan NAA ditimbang $10 \mathrm{mg}$. Hormon BAP dan NAA dimasukkan ke dalam centrifuge tube dan diberi label, kemudian ditambahkan beberapa tetes $\mathrm{KOH} 1 \mathrm{M}$ dan $\mathrm{HCl} 1 \mathrm{M}$ masing-masing untuk NAA dan BAP sambil divorteks hingga larut sempurna. Larutan kemudian ditambahkan dengan aquadest steril hingga volume 10 $\mathrm{mL}$. Konsentrasi yang dibuat adalah 1000 ppm, sehingga penggunaan stok ZPT harus dihitung terlebih dahulu sebelum ditambahkan ke dalam campuran medium dengan rumus pengenceran.

2. Pembuatan Medium Murashige dan Skoog

Pembuatan medium mengacu pada penelitian Chand dkk. (2005) degan modifikasi. Medium instan MS sebanyak 2,66 gram dan dimasukkan ke dalam Erlenmeyer $1 \mathrm{~L}$ yang telah berisi $500 \mathrm{~mL}$ aquadest steril, kemudian ditambahkan dengan sukrosa sebanyak 18 gram. Larutan diaduk dengan menggunakan magnetic stirer hingga larut. Hormon BAP dan NAA masing-masing dimasukkan ke dalam larutan sebanyak $600 \mu \mathrm{L}$ dan diaduk.

Aquades steril ditambahkan hingga volume larutan menjadi $600 \mathrm{ml}$. Kadar keasaman $(\mathrm{pH})$ medium selanjutnya diukur dan diatur hingga berkisar 5,8 - 6, sambil ditambahkan dengan $\mathrm{KOH} 1 \mathrm{M}$ atau $\mathrm{HCl} 1$ M. Larutan medium kemudian ditambahkan dengan agar dan dimasak hingga mendidih. Setelah mendidih, medium dimasukkan ke dalam botol kultur steril dan ditutup dengan aluminium foil.

\section{Sterilisasi Alat dan Medium}

Alat-alat seperti pinset, skalpel, dan petri berisi kertas saring dibungkus dengan kertas payung. Untuk botol kultur dan aquadest steril, botol kultur kosong bersih dan botol kultur yang berisi aquadest ditutup dengan aluminium foil. Alat-alat, botol kultur, aquadest steril, dan medium selanjutnya dimasukkan ke dalam keranjang autoklaf kemudian disterilisasi menggunakan autoklaf dengan suhu $121{ }^{\circ} \mathrm{C}$ dan tekanan 1 atm selama 20 menit. Medium selanjutnya diamati ada atau tidaknya kontaminasi selama 1 minggu.

4. Sterilisasi Eksplan dan Inisiasi Kalus Daun Teh

Medium yang tidak terkontaminasi selanjutnya digunakan sebagai media inisiasi eksplan daun teh. Daun teh yang akan digunakan sebagai eksplan merupakan daun kedua dan ketiga dari pucuk serta berwarna hijau dan sehat dengan ukuran 5$10 \mathrm{~cm}$. Sebelum ditanam pada medium, daun dicuci dengan sabun dan disterilisasi permukaannya dengan metode sterilisasi yang mengacu pada penelitian Putra (2015) dengan modifikasi. Daun yang telah dicuci kemudian disterilisasi dengan larutan sterilan yang berisi $250 \mathrm{mg}$ bakteriosida (Agrept 20 WP), $750 \mathrm{mg}$ fungisida (Diathane M-45), detergen cair, dan air sebanyak $300 \mathrm{~mL}$. Daun selanjutnya direndam dan digojok selama 20 menit.

Sterilisasi eksplan dilanjutkan di dalam LAF dengan menggunakan larutan $\mathrm{NaClO}$, aquadest steril dan tween 20. Larutan $\mathrm{NaClO}$ dibuat dengan variasi konsentrasi 50\%, 30\%, dan 10\%, masingmasing konsentrasi ditambahkan 1-2 tetes tween 20. Sterilisasi dilakukan dengan menggunakan larutan $\mathrm{NaClO} 50 \%$ selama 3 menit, $30 \%$ selama 5 menit, dan $10 \%$ selama 7 menit sambil digojok. Daun kemudian dibilas dengan menggunakan aquadest steril sebanyak tiga kali dengan lama pencucian 3, 7, dan 10 menit. Setelah proses selesai, sterilisasi akhir dilakukan dengan mencelupkan eksplan kedalam etanol 70\% selama 60 detik dan selanjutnya dibiarkan kering diatas kertas saring dan petri steril.

Daun yang telah kering kemudian diiris sebesar $1 \times 1 \mathrm{~cm}$ dan selanjutnya dimasukkan ke dalam botol kultur yang berisikan medium inisiasi. Botol selanjutnya ditutup dengan aluminium foil dan di-wrap dengan plastik wrap. Eksplan diinkubasi pada suhu $25-28{ }^{\circ} \mathrm{C}$ dalam ruangan inkubasi. Eksplan diamati pertumbuhannya setiap minggu. Subkultur 
dilakukan sebelum medium dan kalus sudah berubah warna serta pertumbuhan kalus sudah memenuhi medium.

5. Persiapan Medium elisitasi

Sebelum melakukan proses elisitiasi, medium Murashige dan Skoog cair dibuat terlebih dahulu dengan penambahan larutan $\mathrm{CaSO}_{4}$ dengan konsentrasi $176 \mathrm{~g} / \mathrm{L}$ dan $352 \mathrm{~g} / \mathrm{L}$ dan larutan $\mathrm{CuSO}_{4}$ dengan konsentrasi $1 \mathrm{~g} / \mathrm{L}$ dan $2 \mathrm{~g} / \mathrm{L}$,dan kombinasi keduanya sesuai tabel rancangan perlakuan. Medium yang telah dibuat, selanjutnya diautoklaf dan diamati ada atau tidaknya kontaminasi selama 1 minggu.

\section{Elisitasi}

Sebanyak $0,5 \mathrm{~g}$ kalus selanjutnya ditanam ke dalam masing-masing medium perlakuan. Kultur diinkubasi pada suhu 25 ${ }^{\circ} \mathrm{C}$. Kalus dipanen pada hari ke-0, 5, dan 10. Pemanenan dilakukan dengan mengambil kalus dari mediu kultur, membersihkannya dari medium kultur yang menempel kemudian dikeringkan pada suhu $50{ }^{\circ} \mathrm{C}$ selama 24 jam. Induksi dilakukan dalam keadaan aseptis pada LAF.

\section{Ekstraksi Kalus Daun C. sinensis L.}

Metode ekstraksi pada penelitian ini mengacu pada metode oleh Azwanida (2015) dengan modifikasi, kalus yang telah kering, diambil sebanyak $0,1 \mathrm{~g}$ kemudian digerus menggunakan mortar dan lumpang porselin. Kalus yang telah halus dimasukkan ke dalam centrifuge tube yang telah diberisi metanol absolut sebanyak 3 $\mathrm{mL}$ (perbandingan 1:30). Tube selanjutnya dimasukkan ke dalam alat sonikator dengan suhu ekstraksi $55{ }^{\circ} \mathrm{C}$ selama 40 menit dengan kekuatan $37 \mathrm{kHz}$ pada metode sweep. Setelah ekstraksi selesai, tube di sentrifugasi dengan kecepatan $5000 \mathrm{rpm}$ selama 10 menit. Supernatan kemudian dipindah pada tube baru. Ekstrak selanjutnya disimpan pada suhu $4{ }^{\circ} \mathrm{C}$.

8. Analisis Metabolit Sekunder dengan mengunakan Kromatografi Lapis Tipis

Metode pengujian KLT mengacu pada AHPA (2015) dalam HPTLC Association. Plat silika $60 \mathrm{~F}_{254}$ disiapkan serta ditentukan batas atas dan bawah (1 $\mathrm{cm})$, dengan jarak tempuh eluent adalah 6 $\mathrm{cm}$. Plat selanjutnya dipanaskan pada suhu $100{ }^{\circ} \mathrm{C}$ selama 2 menit. Chamber yang akan digunakan sebelumnya telah dijenuhkan dengan memasukkan fase gerak toluen:aseton:asam format (9:9:2). Sampel dan larutan epikatekin galat selanjutnya ditotolkan pada plat silika sebanyak $5 \mu \mathrm{L}$. Plat dielusi hingga fase gerak mencapai batas akhir. Visualisasi dilakukan pada chamber UV dengan panjang gelombang 254. Hasil visualisasi sampel dibandinginkan dengan standar epikatekin galat.

9. Kuantifikasi Kadar Epikatekin Galat dengan Kromatografi Lapis Tipis

Metode kuantifikasi kadar epikatekin galat dengan menggunakan KLT mengacu pada AHPA (2015) dalam HPTLC Association dengan modifikasi. Plat silika $60 \mathrm{~F}_{254}$ disiapkan serta ditentukan batas atas dan bawah $(1 \mathrm{~cm})$, dengan jarak tempuh eluet adalah $6 \mathrm{~cm}$. Plat selanjutnya dipanaskan pada suhu $100{ }^{\circ} \mathrm{C}$ selama 2 menit. Chamber yang akan digunakan sebelumnya telah dijenuhkan dengan memasukkan fase gerak toluene:aseton:asam format (9:9:2). Sampel dan standar epikatekin galat dengan variasi konsentrasi $50 \mathrm{ppm}, 100 \mathrm{ppm}, 150 \mathrm{ppm}$, 200 ppm, 250 ppm. Selanjutnya, senyawa standar ditotolkan pada plat silika sebanyak $5 \mu \mathrm{L}$. Plat dielusi hingga fase gerak mencapai batas akhir. Visualisasi dilakukan pada chamber UV dengan panjang gelombang 254 dan plat selanjutnya di-scan dengan TLC Scanner. Hasil scan KLT larutan standar kemudian dibuat kurva standar hubungan konsentrasi dengan densitas sehingga didapatkan persamaan garis $\mathrm{Y}=\mathrm{bx}+\mathrm{a}$, dengan $\mathrm{x}$ adalah konsentrasi dan y merupakan densitas. Kadar senyawa selanjutnya dihitung dengan menggunakan persamaan yang didapatkan.

10.Analisis Data

Data yang telah diperoleh selanjutnya diolah dengan menggunakan ANAVA dengan tingkat kepercayaan $95 \%$. Untuk mengetahui beda nyata antara perlakuan yang dengan menggunakan software SPSS 23.0. 


\section{Hasil dan Pembahasan}

Penelitian ini menggunakan eksplan berupa daun teh (Camellia sinensis L.) yang diinduksi pada medium Murashige dan Skoog dengan penambahan hormon Benzyl Amino Purin (BAP) dan Napthalene Acetic Acid (NAA) dengan konsentrasi masing-masing hormon adalah 1 ppm. inisiasi kalu dimulai pada jaringan yang mengalami luka, ini berhubungan dengan sejumlah faktor seperti respon sel terhadap pelukaan, oksigen yang lebih besar dan nutrient yang cukup (Silalahi, 2010). Kalus yang tumbuh memiliki morfologi bertekstur kompak hingga remah, memiliki warna hijau hingga putih kekuningan. Kalus yang terbentuk memiliki bentuk bulat (globular). Warna hijau pada kalus ini terbentuk karena kalus masih memiliki zat hijau daun, namun selama proses subluktur dilakukan kalus yang terbentuk perlahan menjadi remah.

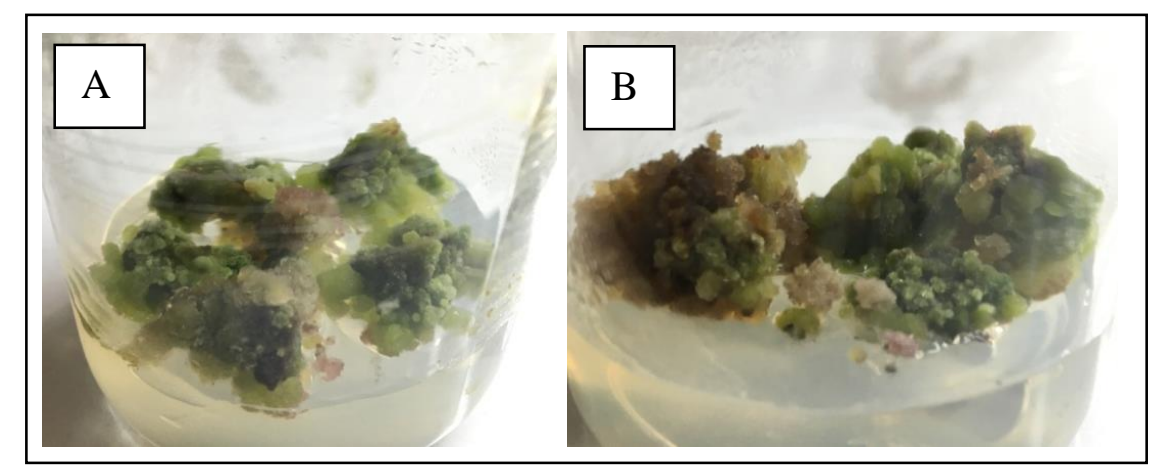

Gambar 1. Kalus hasil pertumbuhan dari eksplan daun teh (Camellia sinensis L.) pada medium Murashige and Skoog, A: kalus kompak, B: kalus remah

Kalus yang terbentuk kalus kompak Camellia sinensis $\mathrm{L}$ yang terbentuk menghasilkan indol alkaloid lebih tinggi 1,92,4 kali dibandingkan dengan kalus remah (Zao et al,, 2001). Kalus kompak dan berwarna hijau disebabkan karena xylem dan floem berkembang dengan baik. Menurut Yelnititis (2012), kalus remah dapat terbentuk karena beberapa hal yakni proses subkultur yang berulang, interaksi antara hormone auksin dan sitokinin pada dosis optimum, stress terhadap ZPT auksin, atau karena sifat tanaman yang secara alami memiliki respon pembentukan kalus remah. Kalus yang terbentuk memiliki warna hijau hingga putih kekuningan seperti pada penelitian Chaturvedi (2013) yang menghasilkan kalus teh yang berwarna hijau pada saat mendapat perlakuan cahaya. Sedangkan warna putih kekuningan atau kuning yang muncul dapat disebabkan karena kalus mengalami pembelahan sel secara terus menerus dan berulang sehingga menyebabkan absennya kloroplas (George, 2008; dan Heryanto, 2014).

Kalus yang telah mengalami subkultur selanjutnya dilakukan proses elisitasi pada medium Murashige dan Skoog padat yang telah ditambahkan dengan elisitor $\mathrm{Ca}^{+}$dan $\mathrm{Cu}^{+}$. Perlakuan konsentrasi $\mathrm{Ca}^{+}$yang digunakan adalah $176 \mathrm{~g} / \mathrm{L}$ dan $352 \mathrm{~g} / \mathrm{L}$ sedangkan $\mathrm{Cu}^{+}$ adalah $1 \mathrm{~g} / \mathrm{L}$ dan $2 \mathrm{~g} / \mathrm{L}$ yang kemudian dilakukan kombinasi kedua elisitor tersebut. Kalus kemudian ditanam pada medium yang telah diberikan senyawa elisitor dan diinkubasi selama 10 hari dengan waktu panen yakni hari ke-0, ke-5, dan ke-10. Pengujian yang dilakukan adalah penentuan kadar epikaten galat pada masing-masing perlakuan.

Sebelum digunakan, kalus yang telah dipanen kemudian dikeringkan pada oven dengan suhu $50{ }^{\circ} \mathrm{C}$ selama 24 jam. Kadar air yang didapat dari hasil pengeringan kalus adalah sebesar $89,99 \%$. Kalus yang telah kering kemudian diekstraksi dengan menggunakan metode sonikasi. Pelarut yang digunakan yaitu metanol dengan perbandingan pelarut adalah 1:30. Kalus kering ditimbang seberat $0,1 \mathrm{~g}$ dan digerus hingga halus.

Pengujian kadar epikatekin galat pada sampel dilakukan dengan menggunakan metode kromatografi lapis tipis (KLT) untuk mendapatkan hasil kualitatif dan kuantitaif. Data kuantitatif didapat berdasarkan perhitungan dengan persamaan regresi linier 
$\mathrm{Y}=\mathrm{ax}+\mathrm{b}$ yang didapat dari pengujian densitas pada deret konsentrasi senyawa epikatekin galat tunggal. Bercak senyawa epikatekin galat pada penelitian ini dapat terlihat secara langsung pada plat tanpa menggunakan reagen pemberi warna, sehingga nilai $\mathrm{Rf}$ dapat langsung dihitung. Hal ini terjadi karena senyawa yang diuji memiliki sifat yang berwarna dibawah cahaya (menyerap warna tampak), sehingga dapat dilakukan visualisasi secara langsung tanpa menggunakan sinar UV (Morlock dan Kovar, 2003 dalam Sherman dan Fried, 2003). Namun, dalam penelitian ini visualisasi dilakukan dibawah sinar UV 254 nm yang menghasilkan visualisasi lebih jelas. Deteksi bercak epikatekin galat yang dilakukan dibawah sinar UV dengan panjang gelombang $254 \mathrm{~nm}$ akan menyebabkan plat terfloresensi sehingga bercak senyawa dapat terlihat. Hasil visualisasi plat kromatografi pada UV 254 (Gambar 1) menunjukkan bercak epikatekin galat kalus sejajar dengan bercak standar dengan Rf sebesar 0,52 dengan warna bercak di bawah sinar UV adalah hitam dan berwarna cokelat di bawah sinar tampak.

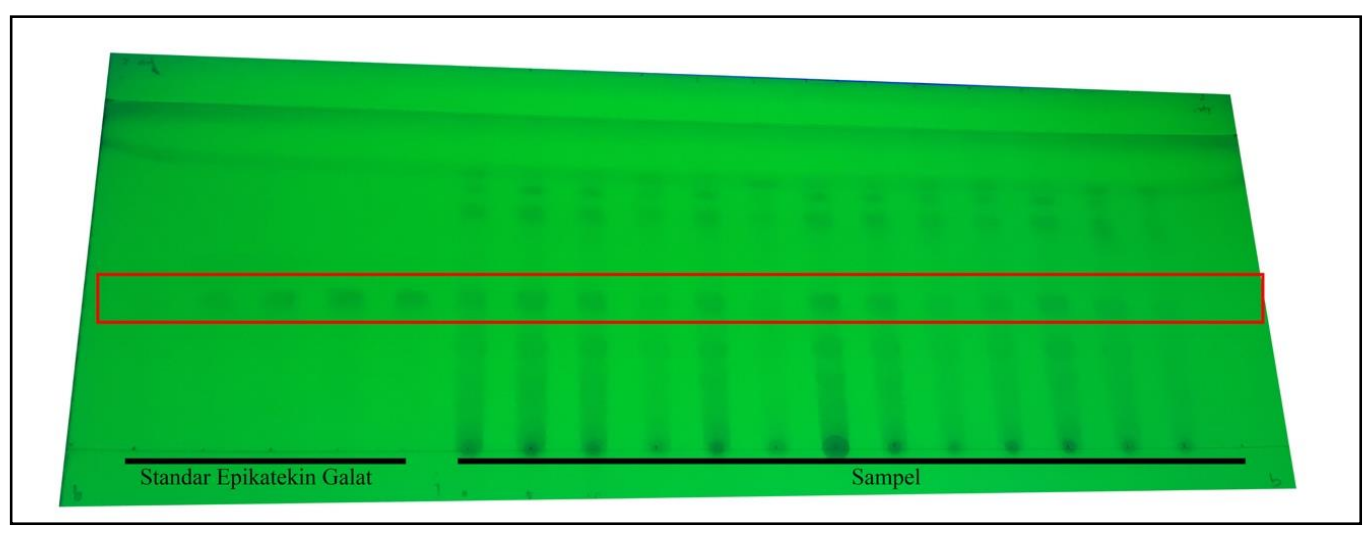

Gambar 2. Hasil visulisasi plat kromatografi pada UV $254 \mathrm{~nm}$ ekstrak kalus hasil elisitasi dengan variasi konsentrasi bubuk $\mathrm{Ca}^{+}$dan $\mathrm{Cu}^{+}$

Nilai Rf senyawa standar epikatekin galat yang dibandingkan dengan bercak elusi KLT pada sampel terdapat pada Rf 0,52 yang sesuai dengan AHPA (2015) yang menyebutkan bahwa nilai $\mathrm{Rf}$ senyawa epikatekin galat adalah 0,52 , epigalokatekin-3O-galat memiliki Rf 0,37, Rf epigalokatekin adalah 0,46 , senyawa epikatekin memiliki $\mathrm{Rf}$ 0,62 . Pengujian kadar epikatekin galat pada sampel dihitung dengan persamaan garis regresi $Y=20,511 x-237,91$ dengan nilai $R^{2}$ sebesar 0,94. Persamaan regresi tersebut didapat dari perbandingan luas area kromatogram dengan konsentrasi yang telah dibuat seri konsentrasi bertingkat yakni 50, 100, 150, 200, dan 250 ppm. Hasil penghitungan konsentrasi senyawa epikatekin gala disajikan pada Tabel 2.

Beberapa perlakuan elisitor elisitor $\mathrm{Ca}^{+}$ dan $\mathrm{Cu}^{+}$penelitian ini tidak terlalu signifikan dalam meningkatkan produksi epikatekin galat dibandingkan dengan kontrol. Pada perlakuan penambahan elisitor tunggal, yaitu penambahan $\mathrm{Ca}^{2+}$ konsentrasi rendah (176 $\mathrm{g} / \mathrm{L})$, dapat meningkatkan konsentrasi epikatekin galat pada masa inkubasi yang lebih lama dibanding perlakuan penambahan $\mathrm{Ca}^{2+}$ dengan konsentrasi lebih tinggi (352 $\mathrm{g} / \mathrm{L})$. Sementara pada lama waktu inkubasi yang sama, penambahan $\mathrm{Cu}^{2+}$ konsentrasi rendah (1 $\mathrm{g} / \mathrm{L})$, dapat meningkatkan konsentrasi epikatekin galat lebih tinggi dibanding perlakuan penambahan $\mathrm{Cu}^{2+}$ dengan konsentrasi lebih tinggi $(2 \mathrm{~g} / \mathrm{L})$. Namun demikian dari hasil kolaborasi kedua perlakuan, yaitu penambahan $\mathrm{Ca}^{2+}$ dan $\mathrm{Cu}^{2+}$, masing-masing dengan konsentrasi rendah $\left(\mathrm{Ca}^{2+}(176 \mathrm{~g} / \mathrm{L})\right.$ dan $\left.\mathrm{Cu}^{2+}(1 \mathrm{~g} / \mathrm{L})\right)$, memberikan pengaruh peningkatan konsentrasi epikatekin galat yang paling tinggi. $\mathrm{Cu}$ merupakan salah satu mikronutrien yang dibutuhkan tumbuhan dalam proses metabolisme dan enzimatik serta mampu mengoptimalkan penggunaan tembaga didalam jaringan. 
Dewi Retnaningati et al.

Tabel 2. Kadar epikatekin galat pada kalus daun C.sinensis L. hasil elisitasi oleh elisitor $\mathrm{Ca}^{+}$dan $\mathrm{Cu}^{+}$

\begin{tabular}{|c|c|c|}
\hline Sampel & Hari & Konsentrasi (ppm) \\
\hline \multirow{3}{*}{ U0A0 } & 0 & 34,15 \\
\hline & 5 & 96,25 \\
\hline & 10 & 153,64 \\
\hline \multirow{3}{*}{ U0A1 } & 0 & 119,15 \\
\hline & 5 & 171,19 \\
\hline & 10 & 156,70 \\
\hline \multirow{3}{*}{ U0A2 } & 0 & 179,26 \\
\hline & 5 & 82,03 \\
\hline & 10 & 44,01 \\
\hline \multirow{3}{*}{ U1A0 } & 0 & 236,38 \\
\hline & 5 & 144,85 \\
\hline & 10 & 193,88 \\
\hline \multirow{3}{*}{ U1A1 } & 0 & 298,37 \\
\hline & 5 & 189,03 \\
\hline & 10 & 25,42 \\
\hline \multirow{3}{*}{ U1A2 } & 0 & 29,31 \\
\hline & 5 & 27,21 \\
\hline & 10 & 52,88 \\
\hline \multirow{3}{*}{$\mathrm{U} 2 \mathrm{~A} 0$} & 0 & 175,42 \\
\hline & 5 & 57,42 \\
\hline & 10 & 34,65 \\
\hline \multirow{3}{*}{ U2A1 } & 0 & 186,48 \\
\hline & 5 & 73,29 \\
\hline & 10 & 117,86 \\
\hline \multirow{3}{*}{$\mathrm{U} 2 \mathrm{~A} 2$} & 0 & 182,71 \\
\hline & 5 & 117,23 \\
\hline & 10 & 59,90 \\
\hline
\end{tabular}

Berdasarkan data yang diperoleh, kondisi yang sering ditemui yaitu semakin meningkatnya konsentrasi elisitor yang ditambahkan ke dalam kultur, senyawa epikatekin galat yang terbentuk semakin menurun. Penurunan ini dapat terjadi karena konsentrasi elisitor yang digunakan melampaui batas optimum. Menurut Dornenburg (2003), jumlah elisitor yang terlalu banyak dapat menurunkan produksi biomasa yang akan berefek pada menurunnya induksi enzim PAL sehingga produksi senyawa antioksidan menjadi terhambat.

Meningkatnya produksi epikatekin galat pada perlakuan dapat disebabkan karena elisitor yang digunakan dikenali sebagai agen pathogen, sehingga kehadirannya mengakibatkan kalus menghasilkan senyawa $\mathrm{H}_{2} \mathrm{O}_{2}$ secara langsung yang akan meningkatkan reactive oxygen species (ROS) serta meningkatnya produksi asam jasmonat dan metil jasmonat endogen. Meningkatnya ROS dan senyawa asam jasmonat serta metil jasmonat endogen ini akan menyebabkan kalus menghasilkan senyawa fenolik dengan bantuan enzim PAL sebagai respon awal pembentukan senyawa fenolik (Srisornkompon dkk., 2014; Abraham dkk., 2011).

Dalam proses biosintesis metabolit sekunder berdasarkan beberapa penelitian yang telah dilakukan, banyak penelitian yang menyatakan bahwa produksi metabolit sekunder (senyawa fenol) terutama epikatekin galat merupakan interaksi yang rumit dari beberapa enzim yakni phenylalanine ammonia lyase (PAL), leucoathocyanidin 4-reductase (LAR), atnhocyanidin synthase (ANS), athocyanidin reductase (ANR), dan enzimenzim lain yang bekerja pada jalur asam sikimat (Punyasiri dkk.,2004; Ververidis dkk., 2007). Menurut Punyasiri dkk. (2004), secara singkat, katekin pada teh disintesis dari leukoatosianidin, leukosianidin, dan leukodephidin, yang akan diubah dengan 
bantuan enzim LAR. Namun, dalam biosintesis epikatekin dan epigalokatekin, leukosianidin bukan merupakan prekursor utama.

Meningkatnya aktivitas enzim PAL akan menyebabkan produksi senyawa-senyawa fenolik meningkat. Salah satunya adalah epikatekin galat. Senyawa epikatekin galat akan terbentuk dari leukosianidin yang akan diubah menjadi antosianidin dengan bantuan anthocyanidin synthase (ANS), selanjutnya antosianidin akan diubah menjadi epikatekin dengan bantuan anthocyanidin reductase (ANR) (Punyasiri dkk., 2004). Akan tetapi, pembentukan derivat dari flava 3-ol seperti epikatekin galat dan epigalokatekin galat secara lengkap masih belum diketahui secara pasti.

\section{Simpulan}

Morfologi dan warna kalus dari eksplan daun $C$. sinensis (L.) pada medium Murashige and Skoog dengan penambahan hormon BAP dan NAA 1 ppm memiliki tekstur kompak dan remah, dengan warna bervariasi yaitu hijau, putih, dan putih kekuningan. Kombinasi elisitor $\mathrm{Ca}^{+}$dan $\mathrm{Cu}^{+}$ yang paling optimal dalam meningkatkan kadar epikatekin galat pada kultur kalus daun C. sinensis (L.) adalah kombinasi elisitor $\mathrm{Ca}^{2+}$ $(176 \mathrm{~g} / \mathrm{L})$ dan $\mathrm{Cu}^{2+}(1 \mathrm{~g} / \mathrm{L})$ selama 0 hari (kurang dari 24 jam).

\section{Daftar Pustaka}

Aebi, H. E. (1984). Catalase in-vitro. Methdos Enzymol 105: 121-126.

AHPA. (2015). Camellia sinensis (Leaf). http://www.botanicalauthentication.org/ind ex.php/Camellia_sinensis_(leaf)\#cite_note -21 .

Azwanida, N. N. (2015). A review on the extraction methods use in medical plants, principle, stregth and limitation. Med Aromat Plants 4(3): 1-6.

Balitbangtan. (2013). Teh merah (Camellia sinensis) hasil eksplorasi di kabupaten Wonosobo. Warta 19(1):1-4.

Balittri, J. T. (2013). Kandungan senyawa kimia pada daun teh (Camellia sinensis). Warta Penelitian dan Pengembangan Tanaman Industri 13(3): 12-16.
Benabadji, S. J., Wen, R., Zheng, J. B., Dong, X. C., \& Yuan, S. G. (2004). Anticarcinogenic and antioxidant activity of diindolymethane derivates. J.Acta Pharmacologica Sinica 25(5): 666-671.

Caldentey, K. M. O., \& Barz, W. H. (2002). Plant biotechnology and transgenic plants. Marcel Dekker. New York.

Chand, G., Sood, A., \& Palni, L. M. S. (2005). Time division cycle in tea (Camellia sinensis) cultures IJTS 4: 1-7.

Chandra, S., Chakraborty, N., Chakraborty, A., Rai, R., Bera, B., \& Acharya, K. (2014). Abiotic elicitor-mediated improvement of innate imunity in Camellia sinensis. J Plant Growth Regul 33: 849-859.

Chobot, V., Huber, C., Trettenhahn, G., \& Hadacek, F. (2009). Cathecin: chemical weapon, antioxidant, or stress regulator. $J$ Chem Ecol 35: 980-996.

Dehpour, A. A., Ebrahimzadeh, M. A., Fazel, N. S., \& Mohamad, N. S. (2009). Antioxidant activity of methanol extract of Ferula assafoetida and its essential oil composition. Grass Aceites 60(4): 405412.

Devasagayam, T. P. A., Kamat, J. P., Mohan, H., \& Kesavan, P. C. (1996). Caffeine as an antioxidant: inhibition of lipid peroxidation induced by reactive oxygen species. Biochim Biophys Acta 1282(1): 63-70.

Dicko, M. H., Gruppen, H., Traore, A. S., Voragen, A. G. J., \& Berkel, W. J. H. (2006). Phenolic compounds and related enzymes as determinants of sorgum for food use. Biotechnology and Molecular Biology Review 1(1): 21-38.

Dornenburg, H. \& Knorr D. (1997). Evaluation of elicitor and high pressure induced enzymatic browning utilizing potato (Solanum tuberosum) suspension cultures as model system for plant tissues. J Agric Food Chem 45: 4173-4177.

George, E. F. (2008). Plant tissue culture procedure background. Plant Propagation by Tissue Culture 1: 65.

George, M. W. \& Tripepi, R. R. (2001). Plant preservative mixture can affect shoot regeneration from leaf explants of chrysanthemum, europan birch, dan rhododendron. HortScience 36(4): 768769. 
Groussard, C., Morel, I., Chevanne, M., Monnier, M., Chillard, J., \& Delamarche A. (2000). Free radical scavenging and antioxidant effects of lactate ion: an in vitro study. $J$ Appl Physiol 89(1): 169-175.

Hazarika, R. R. \& Chaturvedi, R. (2013). Estabilishment of dedifferentiated callus of haploid origin from unfertilized ovaries of tea (Camellia sinensis (L.) O. Kuntze) as a potential source of total phenolic and antioxidant activity. In Vitro Cell Dev.Biol 49: 60-69.

Hendaryono, D. P. S. \& Wijayani, A. (1994). Teknik Kultur Jaringan: Pengenalan dan Petunjuk Perbanyakan Tanaman Tanaman secara Vegetatif Modern. Kanisius. Yogyakarta.

Hendaryono, P. D. S., \& Wijayanti, A., (1994). Teknik kultur jaringan. Kanisius. Yogyakarta.

Henuhili, V. (2013). Kultur Jaringan Tanaman. Fakultas MIPA UNY. Yogyakarta.

Herawan, T. \& Ismail, B. (2009). Penggunaan auksin dan sitokinin untuk menginduksi tunas pada kultur jaringan sengon (Falcataria moluccana) menggunakan bagian kotiledon. Jurnal Pemuliaan Tanaman Hutan 3(1): 23-31.

Heryanto, A. F. (2014). Optimalisasi produksi steviosida dari kalus daun Stevia rebaudiana dengan variasi kombinasi zat pengatur tumbuh [Skripsi]. Universitas Atma Jaya Yogyakarta.

Holme, D. J. \& Peck, H. (1998). Analytical Biochemistry $3^{\text {rd }}$ edition. Prentide Hall Pearson Education. Singapore.

Hounsome, N. \& Hounsome, B. (2011). Handbook of Vegetables and Vegetable Processing. Blackwell Publishing. New Jersey.

Kallitharka, S., Vifuera, C. G., Bridle, P., \& Bakker, J. (1995). Survey of solvents for the extraction of grape seed phenolics. Phytochemical Analysis 6: 265-267.

Kikuzaki, H., Hisamiti, M., Hirose, K., Akiyama, K., \& Taniguchi, H. (2002). Antioxidants properties of ferulic acid and its related compound. J.Agric.FoodChem 50: 21612168.

Kondo, K., Kurihara, M., Miyata, N., Suzuki, T., \& Toyoda, M. (1999). Scavenging mechanism of (-)-epigallocatechin gallate and (-)-epicatechin gallate on peroxyl radicals and formation of superoxide during the inhibitory action. Free Radical Biology \& Medicine 27: 855-863.

Koolman, J. \& Roehm, K. H. (2005). Color Atlas of Biochemistry $2^{\text {nd }}$ Edition. Thieme. New York.

Lu, J. M., Lin, P. H., Yao, Q., \& Chen, C. (2010). Chemical and molecular mechanisms of antioxidants: experimental approaches and model systems. J.Cell. Mol. Med. 14(4): 840-860.

Mahadi, I., Syafi'i, W., \& Sari, Y. (2016). Induksi kalus jeruk kasturi (Citrus microcarpa) menggunakan hormon 2,4-D dan BAP dengan metode in vitro. Jurnal Ilmu Pertanian 21(2): 84-89.

Mahatmanti, F. W. \& Sumarni W. (2003). Kajian termodinamika penyerapan zat warna indikator metil oranye (MO) dalam larutan air oleh adsorben kitosan. Jurnal Kimia FMIPA Universitas Negri Semarang 7(2): $1-19$.

Mallet, T. R. \& Sun, J. (2003). Antioxidant properties of myocardinal fuels. Mol Cell Biochem 253(1-2): 103-111.

Mariska, I. (2013). Metabolit Sekunder: Jalur Pembentukan dan Kegunaannya. http://biogen.libtabng.pertanian.go.id/2013 /metabolit-sekunder-jalur-pembentukandan-keguaannya/.

Martono, Y., \& Martono, S. (2012). Analisis kromatografi cair kinerja tinggi untuk penetapan kada asam galat, kafein, dan epigalokaekin galat pada beberapa produk celup. Agritech 32(4): 362 - 369.

Matsuura, T. \& Kakuda, T. (1990). Effects of precursor, temperatur, and illumination on theanin accumulation in tea callus. Agricultural and Biological Chemistry 54(9): 2283-2286.

Mattel, S. H., \& Smith, H. (1993). Cultural Factor That Influence Secondary Metabolites Accumulation in Plant Cell and Tissue Cultures. Cambridge University. London.

Morlock, G. \& Kovar, K. A. Detection, Identification, and Documentation Thin Layer Chromatography. Marcel Dekker Inc. New York.

Mukhopadhyay, M., Mondal, T. K., \& Chand, P. K. 2016. Biotechnological advances in tea (Camellia sinensis (L.) O. Kuntze): a review. Plant Cell Rep 35: 255-287.

Murashige, T. \& Skoog, F. A. (1962). A revised medium for rapid growth and bioassays 
with tobacco tissue culture physial. Plant 15: 473-497.

Narayanaswamy, S. (1994). Plant Cell and Tissue Culture. McGrawl-Hill. New Delhi.

Nimse, S. B. \& Pal, D. (2015). Free radical, natural antioxidant, and their reaction mechanisms. RSC advance 5: 2798628006.

Oktaria, R., \& Rahmanisa, S. (2016). Pengaruh epigallocatechin-3-gallate (EGCG) pada teh hijau terhadap Acne vulgaris. Majority 5(2): 101-105.

Pardal, S. J. (2012). Regenerasi tanaman secara in vitro dan faktor-faktor yang memengaruhi. http://biogen.litbang.pertanian.go.id/index. php/2012/09/ regenerasi- tanaman-secarain vitro-dan-faktor-faktor-yangmempenaruhi/.

Pramesthi, D.E. (2008). Optimasi suhu dan volume etanol dalam proses meserasi daun stevia (Stevia rebaudiana Bertonii, M) dengan aplikasi desain faktorial [Skripsi]. Universitas Sanata Dharma.

Purwianingsih, W. \& Hamdiyati, Y. (2007). Metode elisitasi menggunakan ragi Saccharomyces cerevisea untuk meningkatkan kandungan bioaktif kuinon Morinda citrifolia. Universitas Pendidikan Indonesia. Bandung.

Roos, W., Evers, S., Hieke, M., Tshope, M., \& Schumann, B. (1998). Shift of intracelluler $\mathrm{pH}$ distribution as part of the signal mechanism leading to the elicitation of benzophenonanthrodine alkaloid. Plant Physion 118: 349-364.

Seran, T. H., Hirimburegama, K., \& Gunasekare, M. T. K. (2016). Somatic embryogenesis from embryogenic leaf callus of tea (Camellia sinensis (1.) Kuntze). Tropical Agricultural Research 18: 1-9.

Setiawati, A., Yuliani, S. H., Gani, M. R., Veronica, E. F., Putri, D. C. A., Putra, R. E., Putra, D. C., Kurniawan, A. M., \& Istyastono, E. P. (2014). Analisis kuantitatif soflafon tempe secara cepat dan sederhana menggunakan kromatografi lapis tipis-densitometer. Jurnal Farmasi Sains dan Komunitas 11(1): 13-17.

Sherma, J. \& Fried, B. (2003). Handbook of ThinLayer Chromatography. Marcel Dekker Inc. New York.
Somantri, R. \& Tanti, K. (2011). Kisah dan Khasiat Teh. Gramedia. Jakarta.

Sousa, C., Lopes, G., Periera, D. M., Taveira, M., Valentao, P., Seabra, R. M., Pereira, J. A., Baptista, P., Ferreres, F., \& Andrade, P. B. (2007). Screening of antioxidant compounds during sprouting of Brassica oleracea L. var. costata DC. Comb Chem High Throughput Screen 10(5): 377-386.

Stahl, E. (1985). Analisis Obat Secara Kromatografi dan Miskroskopi. ITB Press. Bogor.

Sumarno. (2011). Pemuliaan untuk Ketahanan terhadap Hama. Naskah Proceedings Symposium Pemuliaan Tanaman. Perhimpunan Pemuliaan Tanaman Indonesia, Komisariat Daerah Jawa Timur.

Suryowinoto, M. (1991). Budidaya Jaringan dan Manfaatnya. Universitas Gadjah Mada. Yogyakarta.

Sutini. (2010). Produksi Epigakokatein galat pada kultur in vitro kalus Camelia sinensis sebagai kandidat pangan fungsional. Jurnal Rekapangan 9(1): 34-38.

Suvarnalatha, G., Rajendran, L., Ravishandar, G. A., \& Venkataraman, L.V. (1994). Elicitation of anthocyanin production in cell cultures of carrot (Daucus carota L.) by using elicitors and abiotic stress. Biotechnology Letters 16(12): 1275-1280.

Silalahi, M., (2010). Elisitasi peningkatan produksi Ajmalisin oleh kalus Catharantus roseus (L.) G. Don. Berita Biologi jurnal 10(3): 305-311.

Ververidis, F., Trantas, E., Douglas, C., Vollmer, G., Kretzschmar, G., \& Panopoulos, N. (2007). Biotechnology of flavonoids and other phenylpropanoid-derived natural product part1: chemical diversity, impacts on plant biology and human health. Biotechnology Journal 2(10): 1214-1234.

Water, L. R. \& Constabel, F. (1991). Metode Kultur Jaringan Tanaman edisi kedua. Penerbit ITB. Bandung.

Winarsi, H. (2007). Antioksidan Alami dan Radikal Bebas. Kanisius. Yogyakarta.

Zulkarnain, H. (2009). Kultur jaringan: solusi perbanyakan tanaman budi daya. Bumi Aksara.

Jakarta. 